\title{
2 \\ Gender struggles of educated men in the Papuan highlands
}

\author{
Jenny Munro \\ The Australian National University
}

\begin{abstract}
Men are often said to resist, or even lash out against, changing gender norms where they seem likely to advantage women and displace their own authority. As Martha Macintyre succinctly puts it, "For women to gain the control over their own lives and bodies that "eliminating violence" entails, men are going to have to lose it' (2012: 239). Scholarship that foregrounds men's perspectives and lived engagements with contemporary gender values and expectations can contribute nuanced insights into gendered struggles around inequality and cultural change (e.g. Brison 1995; Kempf 2002; Taylor 2008). Drawing on periods of ethnographic research with educated Dani men from the Papuan highlands (Indonesia) between 2005 and 2013, in this chapter I consider what insights can be generated by looking at the experiences and views of men who actively consider and try to pursue modern gender ideals, but whose efforts may be thwarted, go awry, or result in unpredictable outcomes. I conclude that innovative gender ideas are not always translated into practice, and practicing equality in gender relations may be challenged by broader conditions that make unequal relations the path of least resistance. We can improve our understanding of persisting gender inequalities by examining men's struggles with gender values and by asking how gender equalities may be thwarted before they gain traction.
\end{abstract}




\section{Situating indigenous masculinities in highlands Papua}

Papuan masculinities are shaped by competing ideals, challenges, and structural constraints, and are uniquely positioned as Melanesian, Indonesian and indigenous. What Margaret Jolly writes is true for Papua: 'Indigenous masculinities have been formed in relation to, as much as resistance against, hegemonic foreign models; and through such histories, hybrid hegemonies have emerged' (2008: 3). Martin Slama and Jenny Munro (2015) describe the lived space of Papuans as flush with tensions generated by Indonesian views that relegate Papuans to the 'stone-age' (and may wish them to remain there), and 'real-time' practices and conditions in an era of new connections, mobilities and technologies. The notion of being 'left behind' permeates gender as well as ethnic and cultural constructions in Indonesia (Elmhirst 2007), and has been for many decades a claim by which the state advances its power, attempting to displace local forms of authority, understandings and lifeways with 'modern' national ones (Li 1999).

Views from Papua New Guinea, on the other side of the island, describe masculinities in crisis (Knauft 2011) and new articulations of male identity through monetary prowess, commodity consumption, sexual practices and Christian values (Bainton 2008; Cox and Macintyre 2014; Martin 2013). In Papua, the biggest ideological threats to indigenous masculinities are the discourses that relegate cultural practices and values to the tribal past and position culture and black racial heritage as something to be ashamed of (Munro 2015; Stasch 2015). While Papua's frontier economy is burgeoning, it is not controlled by Papuans, and Papuan men are not necessarily the main players in it (Kirksey 2012). Unlike Papua New Guinea, Papuans compete with Indonesians for urban jobs, and are a minority in most urban centres and both provincial capitals. Masculine difference, rather than being constructed primarily around class distinctions, is racialised.

In Indonesia, former dictator Suharto's 'New Order' policies governing civil life until 1998 were emphatically gendered (Robinson 2000: 141). Smoothing out regional and cultural gender variations in this vast archipelago was part of a nationalising process. Pam Nilan suggests that 
'since the end of the New Order in 1998, matters of cultural leadership on gender issues have become more complicated' (2009: 330). Indonesian masculinities now evoke:

various kinds of pressure: to become a good citizen and dependable provider for the family on the one hand, and on the other hand, to match the fantasy images of global 'hypermasculinity' - tough, hard and heroic (ibid.: 327).

Pressures of citizenship and provider, as well as toughness and heroicism, provoke questions of a different character in Papua, where citizenship is more highly contested, at times denied by the state and its security agents, sometimes rejected outright by Papuans who dispute the conditions of their entry into Indonesia in 1963 and the violence and inequality that has been delivered by authorities over the past six decades (see Hernawan 2015). The sort of toughness that might be welcomed on Java is decidedly less welcome among Papuan men, at least from the perspective of government and military personnel trying to silence critiques of the state.

Even if the state's hegemonic efforts to define gender roles have waned, ideologies and practices of development and modernisation continue to shape gender practices, from the domain of everyday life to the interventions devised to change gender inequalities. Although the space of development in Papua so far does not reflect the same focus on, or public messaging about, men that occurs in Papua New Guinea (Lusby 2014 and this volume), for example, there is a similar tendency among development actors to see gender in oversimplified terms for the sake of program implementation. Feryana Wakerkwa (2015) records failed development and government programs in the highlands and other locales in Papua that have tried to unilaterally rectify women's poverty, lack of rights, or disempowerment without involving men in discussions about gender roles, norms or broader power asymmetries.

Nilan (2009) and others argue that the 'Father' (Bapak) masculinity of the Suharto era, in which the bapak held authority over the family, the village and the state in the name of national development, has waned and become more complex over the past decade. In Indonesia more broadly, recent trends and shifts have been influential for gender relations. However, patterns of urbanisation, later age of marriage, fertility control and the rise in women's labour force participation (Jones 2005) cannot be presumed to be occurring in Papua, nor can we surmise that these trends might be having the same impact as they are said to be having 
in the rest of Indonesia. The bapak persona perhaps continues to have a stronger hold in Papua than the rest of Indonesia. In Papua today, bapak is most likely an indigenous man, perhaps the governor or a district head who provides for an entourage of supporters, or perhaps an entrepreneur who commands and controls the livelihoods of a barrage of poor male labourers. He might be a church leader whose commitments promote religious as well as development-related interests among his congregation. Bapak is not unrivalled, as he still competes with Indonesians and the central government for his role in local development (Bertrand 2014; Chauvel 2011).

In Papua as elsewhere it is not only the state, but religious influences as well, that generate particular challenges, tensions and directions for what it means to be a modern man. In Indonesia, religious piety is widely promoted as a modern attribute, and adhering to a world religion is a necessary facet of citizenship, though conservative religious views inscribe gender hierarchies in marriage and family life more generally. Through religion Papuans are connected to other global moderns, and in theory religions promote claims to equality that may otherwise be difficult to come by in Papua (Slama 2015; Timmer 2015).

\section{The Baliem Valley}

The Baliem Valley of the central highlands is the traditional territory of the Dani. Traditionally, Dani men achieved political and social standing by building alliances and redistributing wealth at large-scale ceremonial exchanges of pigs, especially for bride price, which in turn depended on (and generated) wives to create gardens and descendants. Big men achieved standing based on their ability to do good things for others, providing leadership through words, actions and networks (Alua 2006). Women and men engaged in distinct roles and activities, and occupied separate social and physical spaces.

The first permanent presence of foreigners in the valley, namely Catholic and Protestant missionaries who established posts in Wamena in 1954, set in motion new trajectories for gender roles, relations and identities. Male activities were of particular interest to missionaries. Some big men fought against missionaries and protested their agendas, while others sought to draw new authority from affiliations with them (Farhadian 2001, 2003; Naylor 1974). Boys and young men were engaged as religious pupils 
and school students. In the 1960s, the offer of an educational migration to school outside the valley, or being engaged as an indigenous Bible teacher, were some of the first opportunities for a lifestyle not primarily characterised by subsistence horticulture. Particular men's activities and roles were banned or at least discouraged by missionaries, including many forms of exchange, polygamy and tribal war. A 1977 war in the Baliem Valley saw Indonesian troops attacking villages to dispel resistance among those who rejected Indonesian rule, in the name of pacifying tribal warfare. Dani men were overwhelmingly seen as 'primitives' in need of the state's development interventions. Highland men's traditional attire, the penis-sheath (koteka in Indonesian or holim in Dani), symbolised this need for authorities and Indonesian and other onlookers. The first official Indonesian government development intervention in the highlands, Operation Koteka, was named after it.

The city of Wamena, now home to about 40,000 inhabitants, half of whom are indigenous (mainly locals) and half of whom are non-indigenous Indonesian migrants, has emerged as an economic and political hub for the populous, rugged central highlands, despite being accessible only by air. Especially in the city and on its fringes, subsistence horticulture has been abandoned or partially redirected towards a market economy, and indeed many inhabitants around the town are now city dwellers who do not garden at all. Indonesians dominate the commercial sector as shopkeepers and investors and, despite some shifts in hiring patterns, maintain an important presence in government roles. Indonesians also dominate the security sector, which maintains an active presence in the everyday lives of local inhabitants.

Wamena is situated in the oldest administrative district (kabupaten) in the Jayawijaya highlands and, as such, patterns of development, employment and government services differ from the new districts emerging in remote areas. However, Jayawijaya has seen a proliferation of sub-districts, each with an appointed local indigenous inhabitant as subdistrict head. Some employment for indigenous locals has been generated in the bureaucracies of these subdistricts. Employment in road construction or driving trucks are examples of ways that mainly indigenous men engage in 'development' around the district; Dani men express frustration when labour jobs are taken by Indonesians whom they view as physically inferior (Munro and Wetipo 2013; Munro 2015). Wamena attracts many indigenous highlanders to its urban vibe, better functioning services and, usually, 
improved safety and security relative to remote posts and villages where security forces monitor civilians and fight 'separatists' with destructive consequences for local inhabitants.

There are significant tensions between how educated highlands men see themselves and how they are often regarded and treated by Indonesians and, to a lesser extent, coastal Papuans (Munro 2015). Part of this tension arises from the potent ideologies, and overrated promises, of the transformative power of education, which encourage educated men and women to aspire to social status, prestige and respect by virtue of their achievements in spite of potent racism and other structural kinds of oppression. Papuans also regard education as an achievement that confers some superiority, an obligation to do good for others and to contribute to development, as well as a resource that enables resistance. While in Indonesia education has been intended to nationalise and 'homogenise' as much as 'develop' the populace, in Papua (and in other 'remote' areas) education has enveloped a more explicit civilising mission that is now an integral part of Papuans' own understandings of their place in society and options for advancement (see Stasch 2015).

The following case study explores the life of a Dani man I have known since 2005, positioning Yohannes's experiences in the context of his town and neighbourhood, his family and marriage, work and church activities. Rather than normalcy marked by crisis, or continuity marred by disruption, his story demonstrates a persistent struggle to position himself as 'modern', and to enact incipient ideas about gender equality, in spite of constant insecurity and instability.

\section{Yohannes}

Yohannes (not his real name) is a public servant in Wamena. Aged in his $40 \mathrm{~s}$, he is of the first generation of highlanders to complete an Indonesian education from start to finish. Yohannes's education was also a Catholic education; the school was run by Dutch priests as well as teachers from eastern parts of Indonesia. Although his family has land near the Baliem River, Yohannes lives with his wife and two children in the original part of Wamena city referred to as Misi after the Catholic mission.

A bustling market area has grown along the main street near Yohannes's house, along with an orphanage and some motorbike repair shops. The Indonesian-owned and operated shops (kios) line the sides of the street 
while dirt areas in front are occupied by Dani women selling vegetables and fruit. Some shops are now home to game consoles like PlayStation where kids can play for a fee; similarly, Yohannes can charge his mobile phone at a kios if the power is out at home. His neighbourhood was largely destroyed in October 2000 during the worst documented inter-ethnic violence that has ever happened in Papua. The violence broke out when police and other security forces attacked various locations where the Papuan independence flag was raised, killing one person, shooting 10 others, and beating and arresting dozens (Mote and Rutherford 2001). At least 24 migrants and seven Papuans were killed in the melee. Since the incident, a new military command unit has set up near the market. Misi remains one of the most volatile parts of town-a dangerous mix of soldiers, police, new and long-time migrants, and indigenous inhabitants from all over the central highlands, including street youth and those who sniff glue (anak aibon). Fights break out, people are treated violently by police or soldiers, and hungry local inhabitants pace through the overstuffed shops.

From Yohannes's house it is a short walk to the We River, a relatively shallow, turbulent, wide river that drains from the peaks of the snowy Puncak Mountains. In contrast to the multi-ethnic town, across the river are the traditional homes and gardens of Dani and other central highlanders who have moved to the area.

Yohannes first applied for a job in the public service in 2000 when he had only a high school degree. At the time, this should not have been a problem, but when I first met him he had already been trying unsuccessfully for about five years. Then, through what he described as a 'miraculous' series of events, one day in 2008 Yohannes read his name in a list of successful public service entrants published in the provincial newspaper. Despite being happy to be employed, a 'blessing' that he saw as a result of his efforts to be a better Christian, he expressed mixed feelings about his work. While it was essential for earning money he also described it as participating in a state that he does not believe in, and working for a country that does not respect his people and does not consider them worthy of an equal role in their own land. He regrets having to put on a civil servant uniform, which 'makes me feel like I'm in school again' (Wamena, 7 June 2009), but appreciates that unlike many civil servants he actually has work to do at the office, which helps pass the time.

Yohannes's wife, Celestina (not her real name), is an educated woman from his cultural group. He did not pay bride price, unusual at the time, because her father said Celestina was smart and he wanted her to finish 
her schooling and live in the city. Celestina was emotional when she told me about this wish, expressing how fortunate she and Yohannes felt that this was her father's wish for her future. Very progressive, they thought, for a big man with three wives. Yohannes said:

I really felt that responsibility. He was being very generous, and he wanted me to save money for our future and I told him that the main thing, the important thing is that we were going to live in town and Celestina would have a better life and make use of her education (Wamena, 7 June 2009).

Yohannes supported Celestina, and when she finished high school they moved in together. Despite Celestina being the first young woman to graduate from high school from her village (over the bridge), she was not able to get work either, until 2011. Yohannes does not work in a garden, though Celestina divides her time between her garden over the bridge and her public service job. There is a shop near their house where they are in debt from a decade of purchasing rice, noodles, oil and cigarettes on credit while waiting for cash income to materialise.

Yohannes has, over the years, taken more leadership roles in his church, a small parish over the bridge where one of the local men usually leads the service, except for once a month when a Dutch priest comes over to lead mass, conduct baptisms, etc. In particular, he leads the church's youth group as a mentor. This involves leading discussion groups that talk over particular issues with young people, such as marriage, fights and violence, and how to live a more Christian life. Yohannes has financial expectations and time commitments as well, ranging from contributing to all of the community feasts to organising weekly mass and/or youth group activities.

At least since he joined the public service, Yohannes has struggled with alcohol abuse and with violent behaviour during drinking sessions. He started to really drink, he recalls, when colleagues at work invited him to drink with them, and they would hang out after work especially on or after payday, finishing a couple of bottles of whisky (illegal in Wamena). In 2009 he spoke about how he had 'let go' (lepas) of alcohol in conjunction with taking more prominent roles in church and renewing his commitments to being a good Christian. During this time, he focused on mentoring youth, including talking to young men about his experiences with alcohol, such as the time he broke all the windows in his house, or the rather common occasions where he fought with Celestina, shouting abuse or hitting her. $\mathrm{He}$ told me he thanked God that he hadn't done more damage or injury, and felt fortunate that his wife and children were still there with him. 
In 2009, his wife was finally able to get a job in the public service and they both had renewed hopes that they might be able to improve their lives, or at least their house. Their house had always been a sore pointmade of thatched panels, it was falling apart around them, and did little to keep out the cold night air. The roof had fallen in on what was used as a cooking area at the back of the house, so they had gone back to using a fire pit for cooking outdoors. By 2009 there was electricity in the house, but prior to this the children had been reading their school books by candlelight in the evening. With Yohannes receiving half his pay in rice, and the children enrolled at the Catholic school, which charged more fees, there was not enough money, even though Celestina supplied some sweet potatoes and greens from her garden. The family also had some relatives staying with them, at one point a family of four in addition to their other relatives, while the father was away working. They also took on caring for Celestina's sister's daughter Nelly so she could live closer to school. Celestina started work, but as a street cleaner who earned almost no money for her first year of work. During this time, Yohannes also embarked on a university degree program as it was apparent that his high school certificate was not going to be enough for him to keep his job.

During these years there was also some conflict between Celestina and Yohannes over having more children. Yohannes had found himself, in his 40s, wanting more children and since Celestina had not become pregnant he said he suspected it was because either she was secretly using birth control or she had used it at some point in the past and it had rendered her infertile. Celestina, always outspoken, questioned the logic of having more children given their precarious economic situation. It was her recollection that they had agreed about this at some point, though Yohannes seemed to have forgotten their agreement.

In 2013, Yohannes gave Celestina's relative Martin part of their yard and Martin proceeded to build an expensive modern house. It was the sort of house that Yohannes and Celestina had talked about for years. Martin had been working for the provincial government's village development program and through his role in managing and distributing funds had been able to pocket the sort of capital needed to build a good-quality house in Wamena, where the cost of air freight makes everything highly expensive. Shortly thereafter I visited and was surprised to hear that Celestina had left home. Yohannes had been drinking again and had hit Celestina in the face and again damaged the windows in his house. The children, now aged 10 and 13 , were still living with their father. 
There was discussion among the relatives about whether Celestina wanted some sort of compensation to be paid by Yohannes. After a few weeks, they 'resolved the problem' (selesaikan masalah) to use the local phrasing, and Celestina was back home again.

Yohannes's experiences raise a number of themes showing the germination of different gender ideas and practices around bride price, violence, fertility decisions, and female education and employment. A longitudinal view on his life over the span of a decade challenges us to think about violence and alcohol not as problems of uneducated, 'backward' men, but also of educated, progressive men who do not necessarily hold views of women as being 'property', fundamentally inferior, or in need of control by men. In Yohannes's case there were factors to do with other men and their achievements and activities that shaped his struggles with alcohol and violence. His public servant colleagues, both Indonesian and Dani, engaged in binge drinking as an after-hours pastime. His wife's relative, Martin, acquired a lucrative position in the village development program despite having no greater educational attainment than Yohannes. This man was able to build the house that Yohannes and Celestina had been yearning for, right on the land that Yohannes had given to him. It was Martin's wife and three children that Yohannes and Celestina had supported in their home while Martin was away working in other districts.

Relatively early in their marriage, according to Celestina at least, they had decided that they would be more likely to prosper if they limited themselves to having two children, which mirrors the state's promotional messages around birth control. But with the children growing up and very little improvement in their standard of living, Yohannes seemed to be questioning their chosen path of sacrificing the bigger family of typical village life for a small family that could live better in town. It was another massive source of stress for Yohannes that Nelly, the daughter of his wife's sister whom he had raised and put through school, had suddenly turned up pregnant in her first year of high school, perhaps disrupting his notions of female education and men's possible role in supporting it. Family support, influences and pressures play an important role in shaping men's views and actions, as they do in shaping women's and men's expectations of education, employment and marriage (see Spark, this volume).

Yohannes's experiences might give us pause when positioning men as universally resistant to change, or primarily reticent about gender equality and waning authority, though his story is not intended to represent the 
experiences or views of educated highlands men more broadly. Yohannes does not hold particularly strong views against gender equality, nor does he view hitting his wife as appropriate. He does not subscribe to ideas of wife 'ownership' that accompany the commoditisation of bride price (Wardlow 2006). Yet under the influence of alcohol and stress he is still liable to hurt his wife and create chaos in his family home. It is not necessarily that his masculinity is in crisis, and he lashes out, but rather that the constant structural violence injustice and disruption around him challenges his hold on, and ability to act on, modern gender ideals.

In the remainder of the chapter, I examine particular themes from Yohannes's story, specifically marriage and fertility, stigma and 'security' conditions, drawing in comparisons and contrasts with the gender aspirations and practices of other educated men.

\section{Marriage and fertility}

The choice of a spouse, once typically orchestrated by older clan men to build exchange relationships and expand their influence, is an emerging domain in which educated highlands men may try to demonstrate their commitment to modern practices (see Spark, this volume), but in which they are clearly tested by powerful ideas about the beauty, fertility and docility of a young Dani wife. Yohannes was interested in having an educated wife, and a minority of young men in my research have also shared this view. These informants pointed to the economic benefits of having a spouse who would work, probably in the public service, and earn an income, enhancing the couple's position in the 'modern' economy and in town amongst Indonesians. Some men had been raised with the idea that a relatively egalitarian marital partnership (if not necessarily gender equality) is a modern and Christian practice, and that men can demonstrate their own modernity by supporting female education (Cox, this volume; Spark, this volume).

A Protestant university student from Wolo, west of Wamena, referring to friends of his who got pregnant while studying in North Sulawesi, a province of eastern Indonesia, pointed out that in his village, the issue of violence would be considered by relatives before allowing a marriage to go ahead: 
Even if you wait until you are going to finish [university], like Etinus and Ina, well they are still in big trouble back in the village. Because if you go home like that, about to give birth, you can't get married in church and you have to go to the village and talk with every one, all the elders and the family, it's really difficult. They have to decide whether Etinus is good enough, has he ever hit Ina (Jhon, Tondano (North Sulawesi), 3 April 2006).

The possibility of a marital partnership with an educated woman that existed among university students (both male and female) was in tension with the usual practice of marriage in the Baliem Valley in which men prefer a young wife, in line with traditional norms. In and around Wamena, in many cases, men in the age range of 20-40 years, continue to seek out young women (aged 13-18) whom they consider sexually attractive, and if a pregnancy eventuates, the relationship might be formalised into a marriage (see Butt and Munro 2007 for contrasting cases). Young women (around the age of junior high school) spoke of viewing returnee or visiting male university students as attractive partners who actively pursued them, despite what male university students also said about wanting an educated wife.

A longitudinal view of these relationships also reveals that some husbands became more interested in their young wives having more education and employment opportunities over time, especially after she has already given birth to some children. It seems increasingly common for relatives to demand that a young woman should be allowed and supported to continue her education, not just because the family has paid her school fees and gone without her labour in other domains so that she might contribute financially to the family later in life. In extreme cases an irate father has been known to demand that the man who interrupted his daughter's schooling by impregnating her before marriage repay the cost of her school fees.

Fertility is another dimension of educated masculinities that places men at the centre of competing tensions, desires and expectations. Reproduction has emerged as a crucial domain for political questions concerning who should control and define reproductive practices, and how Papuans can respond to becoming marginalised in relation to large numbers of Indonesian migrants (Butt 2005). Producing children is very important to men and women, though, like Yohannes and Celestina, highlanders and other Papuans face strong pressures from various sources to have fewer children, and less frequently, for the sake of improving family prosperity and maternal health (Munro 2014). Educated town-dwellers experience this pressure more intensely, and having fewer children (and in the 'right' circumstances) 
is a palpable way to demonstrate one's commitment to modernity and development (Butt 2005; Butt and Munro 2007). But mobility is an increasingly salient component of education. Being away from home offers up new opportunities for sex, partner choice, and childbearing away, to a certain extent, from the surveillance of kin. Male and female university students have suggested that producing the next generation is of equal importance to higher educational achievements. Mobility, education and parenthood are valued markers of modern adulthood, in spite of concerns about sin and breaking cultural rules about premarital pregnancy (Munro 2012). Dani men attending university away from home were very concerned about the consequences of getting a female student pregnant, though they also enjoyed the pursuit of a partner and gained some self-confidence from out-vying other men for the attention of a woman. As Laurence, a university student living in North Sulawesi said:

My relatives [kakak-kakak, literally older siblings] here do not let me get together with girls; I am not allowed to do it. They watch me all the time. I also do not want to destroy someone's daughter, destroy her education. This is not good. If people get married, they usually get pregnant before long. Parents can be very angry if she does this because they want her to study, to graduate, and to return to Wamena and work in an office. They want her to marry someone with status who can be employed ... if a woman gets pregnant here in Sulawesi, her parents might order her to go home, but other people actually they just let it be. What can they do if she does not want to listen to them. They hope that the man has status and they hope she can finish even if she has married (16 November 2005).

Young men are clearly aware that young women who are studying at university are expected to graduate and obtain formal employment (see Spark, this volume). Still, most men and women expressed that during migration (rantau), abstinence was not realistic nor was it the norm. Because Dani men studying in North Sulawesi vastly outnumbered Dani women, and competed for their attention, many men never found this view tested.

At the same time, birth control and sexual health services were not available to them as unmarried youth (except condoms that could be purchased from some pharmacies). Whether or not young men and women would visit health services and use birth control if it were available raises a host of complex considerations (see Munro 2012, 2014; Butt 2001). One point to make, however, is that even if educated men wished to show commitment to 'modern' ways of relating to women concerning marriage and pregnancy, 
doing so required working against prevailing conditions and broader norms that make it easier than ever before to have sex outside marriage and get a woman pregnant; to pick up junior high school students from their dorms or homestays and to be in multiple relationships at the same time, while being unable to access birth control. Men may or may not protest particular ideas of gender in marriage and family formation, but they might follow the path of least resistance. Even within the controversial and culturally laden topics of marriage and pregnancy we can see desires, not untested, for innovations in gender relations and practices. Were health services appropriate and accessible, were good-quality educational facilities available closer to home, were desirable jobs more available, might these fledgling ideas and commitments to different articulations of gender and sexuality find space to grow?

\section{Racial stigma and 'security'}

Where Yohannes's story highlights stress, not just related to educational expectations, hopes for progress, and structural conditions, other men's experiences more strongly highlight racism, exclusion and violence in shaping educated masculinities and values vis-à-vis women. Avoiding stigma is of particular concern. For example:

Us Papuans are stigmatised as drunks, especially highlanders. The media is always exaggerating stories of us—we like to drink, we like to get drunk, we like to kill each other. Sometimes what is just a family dispute is presented on TV as a tribal war ... So everyone on the outside thinks Papuans are like this ... that's just how things are nowadays (Daniel, student/NGO worker, Wamena, 18 June 2012; Munro and Wetipo 2013: 24).

How highlands Papuan men are seen by others is a concern of young, educated men that brings together a cultural emphasis on reputation, surveillance and observation as salient aspects of sociality. It also involves the state of being watched and judged, not only by Indonesians in Wamena, but also by Indonesians who consume news and travel programming on television, Facebook or other internet platforms (Munro 2015: 188).

Educated men and women from the highlands are among the most ardent and active critics of Indonesian rule in Papua. Papuan men (and less so, women) take up active public roles on issues ranging from human rights abuses to women's economic empowerment, on particular policy decisions as well as electoral politics. Although women's participation is typically 
welcomed, activism is an integral part of how educated men demonstrate 'modern', primarily male-dominated forms of peer leadership while connecting themselves to a broader masculine community. The term 'comrade' (kawan) is a popular way for men to address one another that situates men as always and already part of a political movement/ community, even when used in everyday speech as a term of endearment. Men of Yohannes's age are leading figures in various movements; some of these men have been jailed for political activism by the Indonesian government. Treating educated Papuan male activists in a demeaning fashion, such as in November 2011 when participants in the 3rd Papuan Congress were stripped to their underwear, chained together, and marched to the local police station in Jayapura, is an example of how security forces enforce a pattern of denying Papuan men the status of education and of civilised masculinity (Human Rights Watch 2011). Political activism (such as taking part in demonstrations) is integral to educated masculine identity, positioning men as 'modern' and inclined to recognise rights as well as democratic principles. However, as Papuans their political activism is typically construed by the Indonesian state as disruptive to stability and development, and therefore anti-modern.

Conditions of securitisation and insecurity compel men into positions where they stand off against soldiers or feel the need to stand up for those around them who may have experienced state violence, though only minimal activism focuses on, for example, violence experienced by Papuan women (see Komnas Perempuan 2010). Indonesian authorities sometimes construe these activities as separatist, aggressive behaviours that threaten to destabilise local conditions. What Papuan men and women may see as justifiable protest, local authorities view as another illustration of violent hyper-masculine 'tribal' behaviour. For example, when men converged on a local police station in Enarotali, in the western highlands, in December 2014, to protest about the beating of two youths by Indonesian soldiers the previous night, the police opened fire on the group, killing five young men in their high school uniforms (Human Rights Watch 2014). Racialised fear of Papuan male aggression probably contributed to the police's rash reaction to the noisy, angry crowd. Security sector overreactions to Papuan crowds are an established pattern of state violence, recurring since at least the 1998 Biak Massacre, and repeated during the Wamena incident of 6 October 2000 (mentioned above). The space of protest in Papua has become increasingly violent and militarised, and therefore seen as less appropriate for women's direct involvement. 
A similar tendency to view Papuan men as dangerous and threatening was common among Indonesians in North Sulawesi, and led to Dani and other students feeling stigmatised and being subjected to heightened surveillance from local authorities and police. Views of Papuan students as primitive and uncouth result in locals denying their educational achievements, skills or aspirations to build relationships with Indonesians. Dani efforts to assert these identities have brought them into conflict with Indonesians who expect recognition of a prevailing racialised hierarchy (Munro 2013, 2015).

Looking at everyday conditions of racial stigma and violence helps to reveal the context in which educated men might be striving to position themselves as 'modern' men-endeavours that occur in relation to the presence and views of Indonesians. Acts of violence towards women, intoxication (and violence), acts of protest, in addition to stereotypical views of cultural practices, affirm Indonesian views of Papuans as primitive and uncouth, and avoiding these stereotypes becomes a defining part and clear objective of being a 'modern' man. Desires, if tentative and contingent, to be non-violent, egalitarian, progressive, town-dwelling, educated men, and to eschew stigmas of primitive masculinity, require controlling appearances and how they are seen by others. There is a danger that development interventions may easily tread in the worn pathways of stigmatising men as primitive and violent if they fail to recognise the ways that some men are aspiring to embrace and practice different ways of relating to women and different ways of being men. Similarly, a too easy connection between 'tradition', gender violence and inequality downplays the modern context of violence and abuse in Wamena and other locales. The limitations placed around men's social, political and economic achievements that generate frustrations, jealousies and concerns, may exist in tandem with progressive views and practices, not least because of the need to articulate masculinity in relation to change, or one's temporal positioning in 'real-time', not the 'stone-age'.

\section{Conclusion}

In this chapter I have focused on educated highlands men who are perceived to represent a tribal masculinity of the past, and who are struggling through economic inequalities and political repression. Looking at how educated men engage with issues such as domestic violence, 
marriage, female education, and social/political activism reveals ways that they accept, express, or even embrace equalising gender constructs and practices. These ideas have less to do with educational attainment per se, and only marginally represent the penetration of development interventions on gender norms and rights, which are not widespread in Papua or likely to be sufficiently localised to make an impact. But ideas are not always translated into practice. Yohannes does get drunk and hit his wife. Men like, but also unlike, women are constrained by social and economic structures and gender roles and relations within the family and beyond (Eves 2006; Spark 2010). Living with political violence, racial stigma, lack of health rights (or as Lusby, this volume, discusses, legitimised violence) helps to sediment violence, hierarchy and gender inequalities into everyday life. Even when men pursue 'modern' gender relations in the high-stakes context of avoiding being seen as 'of the stone-age', these possibilities may be thwarted before they gain traction. Expressing, promoting and trying to put into practice ideas that underpin important aspects of gender equality is a path by which men may seek to position themselves as modern, righteous and innovative in a highly stigmatising and violent environment. These intentions can be supported by acknowledging and asking sensitive questions about state violence and racial stigma, and by making pathways to equality less of a struggle.

\section{References}

Alua, Agus A. 2006. 'Ap Kaintek Model Kepemimpinan Masyarakat Hubula di Lembah Balim, Papua'. In Nilai-Nilai Hidup Masyarakat Hubula di Lembah Balim Papua (2nd edn), ed. Nico A. Lokobal, Agus A. Alua, Thadeus N. Mulait, pp. 139-65. Jayapura: Biro Penelitian Sekolah Tinggi Filsafat Fajar Timur.

Bainton, Nicholas A. 2008, 'Men of kastom and the customs of men: Status, legitimacy and persistent values in Lihir, Papua New Guinea'. The Australian Journal of Anthropology 19(2): 194-212. doi. org/10.1111/j.1835-9310.2008.tb00122.x.

Bertrand, Jacques. 2014. 'Autonomy and stability: The perils of implementation and 'divide-and-rule' tactics in Papua, Indonesia'. Nationalism and Ethnic Politics 20(2): 174-99. doi.org/10.1080/1353 7113.2014.909157. 
Brison, Karen. 1995. 'Changing constructions of masculinity in a Sepik society'. In Politics of Culture in the Pacific Islands, part II. Special Issue: Ethnology 34(3) (Summer): 155-75. doi.org/10.2307/3773820.

Butt, Leslie. 2015. 'Living in HIV-land: Mobility and seropositivity in highlands Papua'. In From 'Stone Age' to 'Real Time': Exploring Papuan Temporalities, Mobilities, and Religiosities, ed. Martin Slama and Jenny Munro, pp. 221-42. Canberra: ANU Press. Online: press.anu.edu. $\mathrm{au} /$ publications/series/monographs-anthropology/stone-age-real-time (accessed 24 August 2016).

. 2005. 'Sexuality, the state, and the runaway wives of highlands Papua, Indonesia'. In Sex in Development: Science, Sexuality, and Morality in Global Perspective, ed. Vincanne Adams and Stacy Leigh Pigg, pp. 163-85. Durham: Duke University Press. doi. org/10.1215/9780822386414-008.

- 2001. 'KB kills: Political violence, birth control, and the Baliem Valley Dani'. The Asia Pacific Journal of Anthropology 2(1): 63-86.

Butt, Leslie and Jenny Munro. 2007. 'Rebel girls? Unplanned pregnancy and colonialism in highlands Papua, Indonesia'. Culture, Health \& Sexuality 9(6): 585-98. doi.org/10.1080/13691050701515324.

Chauvel, Richard. 2011. 'Policy failure and political impasse: Papua and Jakarta a decade after the "Papuan Spring". In Comprehending West Papua, ed. Peter King, Jim Elmslie and Camellia Webb-Gannon, pp. 105-15. Centre of Peace and Conflict Studies. Sydney: University of Sydney.

Cox, John and Martha Macintyre. 2014. 'Christian marriage, money scams, and Melanesian social imaginaries'. Oceania 84(2): 138-57. doi.org/10.1002/ocea.5048.

Elmhirst, Rebecca. 2007. 'Tigers and gangsters: Masculinities and feminised migration in Indonesia'. Population, Space and Place 13(3): 225-38. doi.org/10.1002/psp.435. 
Eves, Richard. 2006. Exploring the Role of Men and Masculinities in Papua New Guinea in the 21st Century: How to Address Violence in Ways that Generate Empowerment for Both Men and Women. Report for Caritas Australia. Online: xyonline.net/sites/default/files/ Eves,\%20Exploring\%20role\%20of\%20men\%20PNG.pdf （accessed 17 November 2016).

Farhadian, Charles Edward. 2003. 'Comparing conversions among the Dani of Irian Jaya'. In The Anthropology of Religious Conversion, ed. Andrew Buckser and Stephen D. Glazier, pp. 55-68. Oxford: Rowman \& Littlefield.

__ 2001. 'Raising the morning star: A social and ethnographic history of urban Dani Christians in New Order Indonesia'. PhD dissertation. Boston University.

Gardner, Robert and Karl Heider. 1968. Gardens of War: Life and Death in the New Guinea Stone Age. London: Deutsch.

Hernawan, Budi. 2015. 'Torture as a mode of governance: Reflections on the phenomenon of torture in Papua, Indonesia'. In From 'Stone Age' to 'Real Time': Exploring Papuan Temporalities, Mobilities, and Religiosities, ed. Martin Slama and Jenny Munro, pp. 195-220. Canberra: ANU Press. Online: press.anu.edu.au/publications/series/ monographs-anthropology/stone-age-real-time (accessed 24 August 2016).

Human Rights Watch. 2014. 'Indonesia: Security forces kill five in Papua'. Online: www.hrw.org/news/2014/12/10/indonesia-security-forceskill-five-papua (accessed 9 September 2016).

—_. 2011. 'Indonesia: Independent investigation needed into Papua violence'. Online: www.hrw.org/news/2011/10/28/ indonesia-independent-investigation-needed-papua-violence (accessed 9 September 2016).

Jolly, Margaret. 2008. 'Moving masculinities: Memories and bodies across Oceania'. The Contemporary Pacific 20(1): 1-24. doi.org/10.1353/ cp.2008.0010.

Jones, Gavin W. 2005. 'The "flight from marriage" in South-east and East Asia'. Journal of Comparative Family Studies 36(1) (Winter): 93-119. 
Kempf, Wolfgang. 2002. 'The politics of incorporation: masculinity, spatiality and modernity among the Ngaing of Papua New Guinea'. Oceania 73(1): 56-77.

Kirksey, Eben. 2012. Freedom in Entangled Worlds: West Papua and the Architecture of Global Power. Durham, NC: Duke University Press. doi.org/10.1215/9780822394761.

Knauft, Bruce M. 2011. 'Men, modernity and Melanesia'. In Echoes of the Tambaran: Masculinity, History and the Subject in the Work of Donald F. Tuzin, ed. David Lipset and Paul Roscoe, pp. 103-114. Canberra: ANU E Press. Online: press.anu.edu.au/publications/series/monographsanthropology/echoes-tambaran (accessed 24 August 2016).

Komnas Perempuan. 2010. Stop sudah! Kesaksian perempuan Papua korban kekerasan dan pelanggaran HAM, 1963-2009. Komnas Perempuan, Pokja Perempuan Majelis Rakyat Papua. Jakarta: International Center for Transitional Justice.

Li, Tania Murray. 1999. 'Compromising power: Development, culture, and rule in Indonesia'. Cultural Anthropology 14(3): 295-322. doi. org/10.1525/can.1999.14.3.295.

Lusby, Stephanie. 2014. 'Preventing violence at home, allowing violence in the workplace: A case study of security guards in Papua New Guinea'. State Society and Government in Melanesia, in brief 2014/49. Canberra: The Australian National University.

Macintyre, Martha. 2012. 'Gender violence in Melanesia and the problem of Millennium Development Goal No. 3'. In Engendering Violence in Papua New Guinea, ed. Margaret Jolly, Christine Stewart with Carolyn Brewer, pp. 239-66. Canberra: ANU E Press. Online: press.anu.edu. $\mathrm{au} /$ publications/engendering-violence-papua-new-guinea (accessed 23 August 2016).

Martin, Keir. 2013. The Death of the Big Men and the Rise of the Big Shots: Custom and Conflict in East New Britain. New York and Oxford: Berghan Books.

Mote, Octovianus and Danilyn Rutherford. 2001. 'From Irian Java to Papua: The limits of primordialism in Indonesia's troubled east'. Indonesia 72 (October): 115-40. doi.org/10.2307/3351483. 
Munro, Jenny. 2015, “Now we know shame”: Malu and stigma among highlanders in the Papuan diaspora'. In From 'Stone Age' to 'Real Time': Exploring Papuan Temporalities, Mobilities, and Religiosities, ed. Martin Slama and Jenny Munro, pp. 169-94. Canberra: ANU Press. Online: press.anu.edu.au/publications/series/monographs-anthropology/ stone-age-real-time (accessed 24 August 2016).

—_. 2014. 'Papuan perspectives on family planning, fertility and birth control'. State, Society and Government in Melanesia, discussion paper 2014/7. Canberra: The Australian National University.

- _ 2013. 'The violence of inflated possibilities: Education, transformation and diminishment in Wamena, Papua'. Indonesia 95(April): 25-46.

__. 2012. “'A diploma and a descendant!” Premarital sexuality, education, and politics among Dani university students in North Sulawesi, Indonesia'. Journal of Youth Studies 15(8): 1011-1027. doi. org/10.1080/13676261.2012.693592.

Munro, Jenny and Patricio Wetipo. 2013. Prevalensi minuman lokal di Wamena, Papua: laporan hasil diskusi dan rekomendasi dari masyarakat. Online: www.academia.edu/5482245/Prevalensi_Minuman_Lokal_ di_Wamena_Papua_Laporan_Awal (accessed 24 August 2016).

Naylor, Larry Lee. 1974. 'Culture change and development in the Balim Valley, Irian Jaya, Indonesia'. PhD dissertation, Southern Illinois University.

Nilan, Pam. 2009. 'Contemporary masculinities and young men in Indonesia'. Indonesia and the Malay World 37(109): 327-44. doi. org/10.1080/13639810903269318.

Robinson, Katherine. 2000. 'Indonesian women: from Orde Baru to Reformasi'. In Women in Asia: Tradition, Modernity and Globalisation, ed. Louise Edwards and Mina Roces, pp. 139-69. St Leonards: Allen \& Unwin. 
Slama, Martin. 2015. 'Papua as an Islamic frontier: Preaching in "the jungle" and the multiplicity of spatio-temporal hierarchisations'. In From 'Stone Age' to 'Real Time': Exploring Papuan Temporalities, Mobilities, and Religiosities, ed. Martin Slama and Jenny Munro, pp. 243-70. Canberra: ANU Press. Online: press.anu.edu.au/ publications/series/monographs-anthropology/stone-age-real-time (accessed 24 August 2016).

Slama, Martin and Jenny Munro. 2015. 'Exploring Papuan temporalities, mobilities and religiosities: An introduction'. In From 'Stone Age' to 'Real Time': Exploring Papuan Temporalities, Mobilities, and Religiosities, ed. Martin Slama and Jenny Munro, pp. 1-38. Canberra: ANU Press. Online: press.anu.edu.au/publications/series/monographsanthropology/stone-age-real-time (accessed 24 August 2016).

Slama, Martin and Jenny Munro (eds). 2015. From 'Stone Age' to 'Real Time': Exploring Papuan Temporalities, Mobilities, and Religiosities. Canberra: ANU Press. Online: press.anu.edu.au/publications/series/ monographs-anthropology/stone-age-real-time (accessed 24 August 2016).

Spark, Ceridwen. 2010. 'Changing lives: Understanding the barriers that confront educated women in Papua New Guinea'. Australian Feminist Studies 25(63): 17-30. doi.org/10.1080/08164640903499901.

Stasch, Rupert. 2015. 'From primitive other to Papuan self: Korowai engagement with ideologies of unequal human worth in encounters with tourists, state officials, and education'. In From 'Stone Age' to 'Real Time': Exploring Papuan Temporalities, Mobilities, and Religiosities, ed. Martin Slama and Jenny Munro, pp. 59-94. Canberra: ANU Press. Online: press.anu.edu.au/publications/series/monographsanthropology/stone-age-real-time (accessed 24 August 2016).

Taylor, John P. 2008. 'The social life of rights: "gender antagonism", modernity and raet in Vanuatu'. The Australian Journal of Anthropology 19(2): 165-78. 
Timmer, Jaap. 2015. 'Papua coming of age: The cycle of man's civilisation and two other Papuan histories'. In From 'Stone Age' to 'Real Time': Exploring Papuan Temporalities, Mobilities, and Religiosities, ed. Martin Slama and Jenny Munro, pp. 95-124. Canberra: ANU Press. press. anu.edu.au/publications/series/monographs-anthropology/stone-agereal-time (accessed 24 August 2016).

Wakerkwa, Feryana. 2015. 'Does empowerment really achieve the goal of improving women's lives in Papua and West Papua?' Paper presented at the Pacific Research Colloquium, The Australian National University, Canberra, January-February 2015.

Wardlow, Holly. 2006. Wayward Women: Sexuality and Agency in a New Guinea Society. Berkeley: University of California Press. 
This text is taken from Transformations of Gender in Melanesia, edited by Martha Macintyre and Ceridwen Spark, published 2017 by ANU Press, The Australian National University, Canberra, Australia. 